\title{
Secondary spontaneous pneumothorax complicating miliary tuberculosis in a young woman
}

\author{
Amit Shankar Singh, Virendra Atam, Liza Das
}

Department of Medicine, King George's Medical University, Lucknow, Uttar Pradesh, India

\section{Correspondence to} Dr Amit Shankar Singh, amitkgmumedicine@gmail.com

\section{DESCRIPTION}

A 17-year-old girl from a rural part of Uttar Pradesh in India presented with high-grade fever of 2-month duration along with fatigability and weight loss. She had no symptoms of cough, breathlessness, chest pain, headache, backache or multiple swellings over the body. The patient was asymptomatic earlier with no history of chronic cough, fever or haemoptysis. She does have history of contact with her elder brother currently suffering from active pulmonary tuberculosis infection and on antitubercular medications. On examination, the patient was febrile with oral temperature fluctuating from $102^{\circ} \mathrm{F}$ to $103^{\circ} \mathrm{F}$, pulse rate $106 /$ $\mathrm{min}$, blood pressure 110/60 $\mathrm{mm} \mathrm{Hg}$ and respiratory rate 20 breaths/min with $95 \%$ oxygen saturation on room air. On systemic examination, lymphadenopathy or any organomegaly was absent. During the workup for her fever, white cell counts were $11200 / \mu \mathrm{L}$ with $54 \%$ lymphocytes and $46 \%$ polymorphs. Chest X-ray of the patient showed multiple pattern of diffuse, randomly distributed, well-defined small $1-2 \mathrm{~mm}$ opacities throughout lung (figure 1). Antitubercular treatment started following which fever subsided, but she again visited our emergency department after 10 days with sudden breathlessness, tachypnoea and low oxygen saturation. Her blood pressure was 90/ $50 \mathrm{~mm} \mathrm{Hg}$, heart rate 136 beats per minute and was severely hypoxic (oxygen saturation 43\%) despite oxygen inhalation. Examination of the patient showed deviation of trachea and signs of

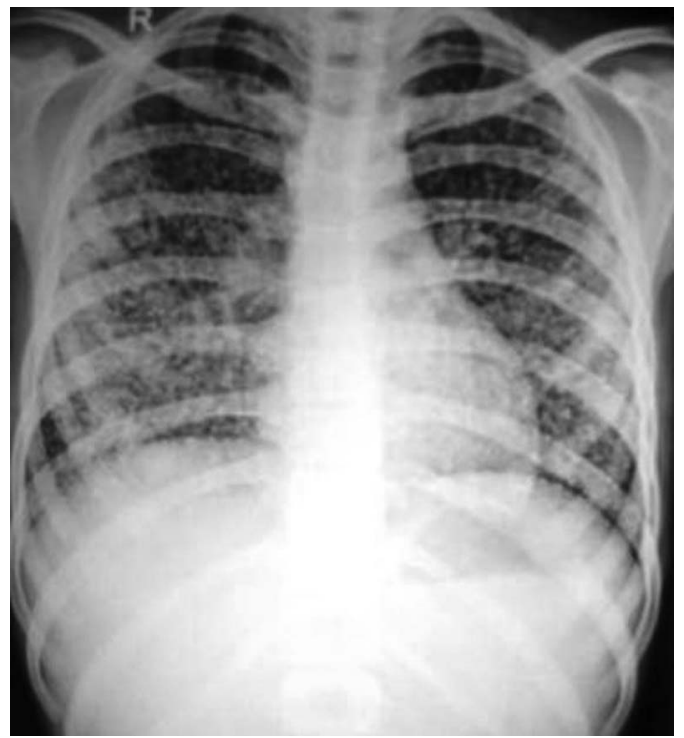

Figure 1 Chest X-ray posteroanterior view showing multiple miliary shadows.

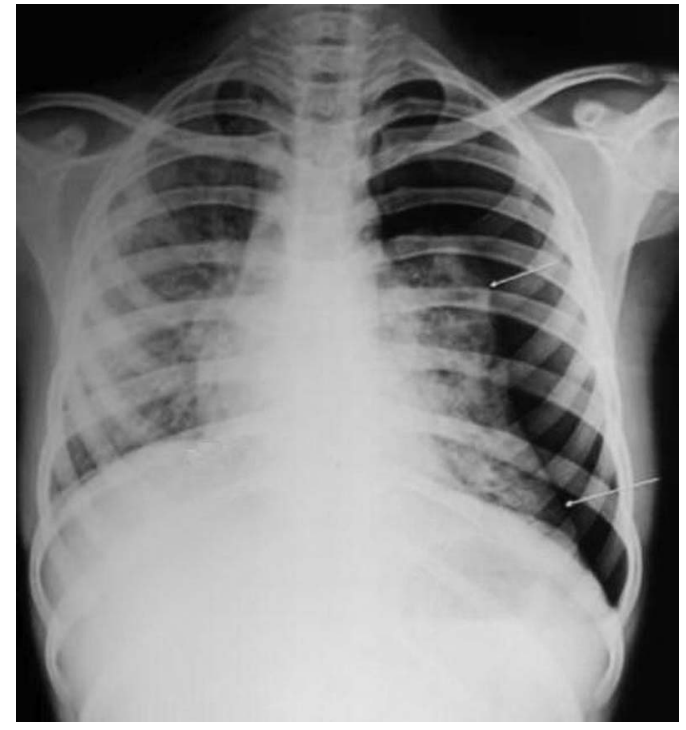

Figure 2 Chest X-ray posteroanterior view showing left-sided pneumothorax with light index $72.54 \%$ and shifting of mediastinum to opposite side. The light index is calculated as the size of the pneumothorax (in \%)=(1 $\left.-D_{L}^{3} / D_{H T}^{3}\right) \times 100$, where $D_{L}$ is the diameter of the collapsed lung measured at the hilar level and $D_{\mathrm{HT}}$ is the internal diameter of the hemithorax on collapsed side measured at the hilar level.

mediastinal shift to the right side. Chest X-ray this time showed left-sided pneumothorax with light index $72.54 \%$ and shifting of mediastinum to opposite side suggestive of large pneumothorax (figure 2). Immediate tube thoracostomy with a chest tube (24 French) attached to a water-seal device relieved symptoms of the patient drastically.

A secondary spontaneous pneumothorax (SSP) is defined as a pneumothorax that occurs as a complication of underlying lung disease. ${ }^{1}$ Nearly every lung disease can be complicated by SSP, although the most commonly associated diseases are chronic obstructive pulmonary disease, cystic fibrosis, primary or metastatic lung malignancy and necrotising pneumonia (eg, bacterial or fungal pneumonia, pneumocystis pneumonia and tuberculosis). ${ }^{2}$ Although miliary pattern and pneumothorax are rare radiological features in pulmonary tuberculosis, their incidences are nearly $1.3 \%$ and $1.5 \%$, respectively. ${ }^{3}$ Pneumothorax is a rare and potentially life-threatening complication of miliary tuberculosis. The pathogenesis of pneumothorax in miliary tuberculosis is unclear, but the following mechanisms can be considered-caseation or necrosis of subpleural miliary nodules and their subsequent rupture can cause pneumothorax. 


\section{Learning points}

- Miliary tuberculosis is a disseminated form of tuberculosis with distinctive pattern in chest X-rays.

- Miliary tuberculosis of lungs can lead to devastating complications like pneumothorax.

- Secondary spontaneous pneumothorax occurs in patients with already compromised lung function; so often presents as a potentially life-threatening disease, requiring immediate action.
Competing interests None.

Patient consent Obtained.

Provenance and peer review Not commissioned; externally peer reviewed.

\section{REFERENCES}

1 Sahn SA, Heffner JE. Spontaneous pneumothorax. N Engl I Med 2000;342: $868-74$.

2 Noppen M, De Keukeleire T. Pneumothorax. Respiration 2008;76:121.

3 Aktogu S, Yorgancioglu A, Cirak K, et al. Clinical spectrum of pulmonary and pleural tuberculosis: a report of 5,480 cases. Eur Respir J 1996;9: 2031-5.

Copyright 2014 BMJ Publishing Group. All rights reserved. For permission to reuse any of this content visit http://group.bmj.com/group/rights-licensing/permissions.

BMJ Case Report Fellows may re-use this article for personal use and teaching without any further permission.

Become a Fellow of BMJ Case Reports today and you can:

- Submit as many cases as you like

- Enjoy fast sympathetic peer review and rapid publication of accepted articles

- Access all the published articles

- Re-use any of the published material for personal use and teaching without further permission

For information on Institutional Fellowships contact consortiasales@bmjgroup.com

Visit casereports.bmj.com for more articles like this and to become a Fellow 